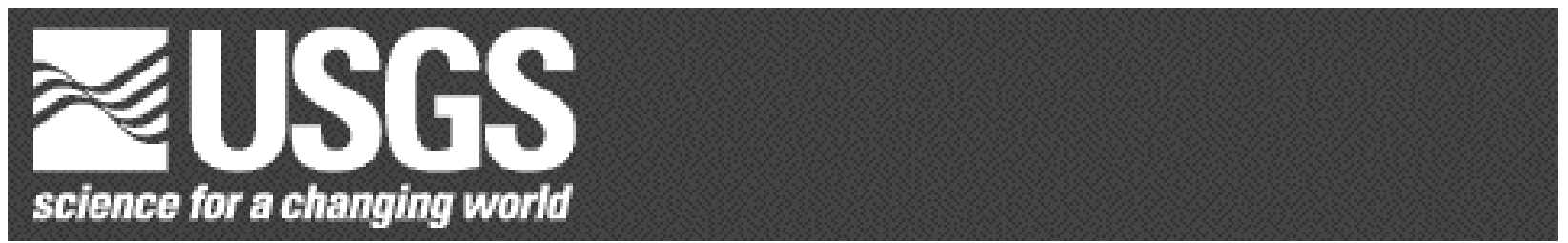

\title{
PRELIMINARY LOCATION AND AGE DATABASE FOR INVERTEBRATE FOSSILS COLLECTED IN THE SAN FRANCISCO BAY REGION, CALIFORNIA
}

Compiled by John M. Parker, William B. West, William T. Malmborg, and Earl E. Brabb ${ }^{1}$

Open-File Report 03-465

2003

This report is preliminary and has not been reviewed for conformity with U.S. Geological Survey editorial standards or with the North American Stratigraphic Code. Any use of trade, firm, or product names is for descriptive purposes only and does not imply endorsement by the U.S. Government.

U.S. DEPARTMENT OF THE INTERIOR

U.S. GEOLOGICAL SURVEY

${ }^{1}$ Menlo Park, Calif. 


\section{INTRODUCTION AND BACKGROUND}

\subsection{Need for information}

Most geologic maps published for central California in the past century have been made without the benefit of microfossils. The age of Cretaceous and Tertiary rocks in the structurally complex sedimentary formations of the Coast Ranges is critical in determining stratigraphic succession and in determining whether the juxtapositon of similar appearing formations means that a fault is present. Since the 1930's, at least, oil company geologists have used microfossils to assist them in geologic mapping and in determining the environments of deposition of sedimentary rocks. This information has been confidential, but in the past 20 years the attitude of petroleum companies about this information has changed, and much material is now available. We report here on approximately 4,700 samples, largely foraminifers, from surface localities in the San Francisco Bay region of California. The information contained here can be used to update geologic maps, to analyze the depth and temperature of ocean water covering parts of California during the Mesozoic and Cenozoic eras, and for solving other geologic problems.

\subsection{USGS Project in the 1970's}

An experimental USGS project in the early 1970's to prepare geologic maps for the San Francisco Bay region provided an opportunity to persuade petroleum companies to make available geologic and paleontologic (hereinafter abbreviated to paleo) data to help complete the mapping. Exxon and Unocal Petroleum Companies provided geologic maps and paleo reports based on foraminifers collected by their geologists from Vacaville in Solano County to San Luis Dam in Merced County. Some of the geologic maps were released with only minor modifications (Brabb and others, 1971) and others were incorporated into maps covering large areas in Solano and Napa Counties (Sims and others, 1973).

\subsection{USGS Project beginning 1985}

A second USGS project began in 1985 to prepare digital geologic maps of the San Francisco Bay region. Geologic maps for almost all the area are published and currently available. Refer to the USGS San Francisco Bay Area geology website (http://sfgeo.wr.usgs.gov).

The Arco, Shell, Exxon, Unocal, and Chevron Petroleum Companies contributed an additional 15,000 slides and vials of foraminifer samples along with a few geologic maps and paleo reports. The paleo reports identify the location, type of fossils, and age of most of these samples. These data helped in the making of the digital geologic maps of the San Jose 1:100,000 quadrangle (Wentworth and others, 1999), Contra Costa County (Graymer and others, 1994), Alameda County (Graymer and others, 1996), Santa Cruz County (Brabb, 1997), San Mateo County (Brabb and others, 1998), and San Francisco, Marin, Sonoma, Napa, and parts of other counties in the northern San Francisco Bay region (Blake and others, 2000, 2002, and Graymer and others, $2002 \mathrm{a}, 2002 \mathrm{~b}$ in press). Chevron also provided sonic logs for many oil test wells in the San Francisco Bay region that show the depth of different geologic units and their density. These and other data have been used by Wentworth and others (1997) and Jachens and others (1997) to help prepare a 3-D seismic-velocity model to explain the propagation of seismic waves from local earthquakes.

The original locality maps for Chevron fossils are in the USGS library in Menlo Park, California, and copies of these maps along with the foraminifer slides, residues, card files, and other materials are at the Invertebrate Zoology and Geology Department, California Academy of Sciences in San Francisco. Additional materials have been given to the Earth Sciences Department, California State University, Long Beach. 


\section{प1.4 Digital files}

The availability of digital geologic maps for the San Francisco Bay region stimulated the idea of having all the paleo information for each county available in digital form. Ideally, any portion of a geologic map could be displayed on a computer screen with the paleo localities shown. When a point is selected, a data sheet would be opened providing locality and geologic information, the types of fossils collected, who examined them, the age determined, any related published reports, and the repository of the fossil material. The present report is a step in that direction.

\subsection{Scope of this report}

Information for more than 4,500 paleo collections from 174 USGS 7.5' quadrangles is provided in a database. Many of the localities have been plotted on digital geologic maps, but that database is not yet ready for release. A previous report listing all the Chevron foraminifer samples from surface localities in California has been released (Brabb and Parker, 2003), but that report lists only the bare essentials of locality and age information. The present report is much more extensive and includes many collections not in the previous report, including information from other oil companies, universities, and the U. S. Geological Survey (USGS) collections.

\section{ORGANIZATION OF THE DATA}

The data collected here is divided into 14 parts: 1) the date the data sheet was prepared, 2) main and subordinate locality numbers, 3 ) location by geographic coordinates, principal landmarks, elevation, and stratigraphic position of the fossils, if known, 4) the name of the $7.5^{\prime}$ quad map and the county, 5) the name of the geologic formation from which the fossils came and the author and title of the map used to obtain the name, 6) the age of the fossils, 7) the lithology, 8) the name of the collector and the year of collection, 9) the type of fossils used to determine the age, 10) the name of the paleontologist providing the analysis and the year the sample was examined, 11) the environment of deposition inferred from the fossils, 12) the repository for the fossils, 13) references to publications mentioning the fossils, and 14) remarks, including notations by the collector or the paleontologist.

The information provided is provisional and needs editing to reflect the changes made in geologic mapping during the past 10 years. Much of the information is taken verbatim from the original sources and has not been updated to reflect modern stratigraphic names and nomenclature. Location information, however, has been plotted on modern topographic maps. Similiarly, most of the names of geologic formations have been taken from the newly released digital geologic maps for the San Francisco Bay Region.

\section{PREPARATION OF THE DATA SET}

A data sheet using FileMaker Pro version 3.0 v.1 was prepared for each fossil locality from geologic and locality maps, fossil reports, and field notebooks provided by petroleum companies, universities, and by USGS geologists. Preparation of the data sheets has been done by volunteers over a period of 11 years.

\section{AGE OF SAMPLES}

Most of the age determinations are from previously confidential reports prepared by paleontologists from the Chevron, Exxon, and Unocal Petroleum Companies. Many of their notes are 
accompanied by stratigraphic columns, cross-sections, foraminifer check lists, sketch maps, and other materials. The age determinations are based on the biostratigraphy at the time these materials were examined, and no attempt has been made to bring the information up to date. Some of the data had previously been released in reports by students at Stanford University, the University of California, Berkeley, and San Jose State University. Additional age determinations were provided by USGS paleontologists, many of them in USGS Open-File Reports.

The ages of the foraminifers from petroleum company reports follows the zonation of Goudkoff (1942) for the Cretaceous, modified by internal and informal zones; Laiming (1940) for the Eocene; and Kleinpell (1938) for the Oligocene and Miocene.

\section{SUMMARY}

The location and age of approximately 4,700 fossil collections in the San Francisco Bay region of California are provided. Most of these data have not previously been released. The original foraminifer material has been given to the California Academy of Sciences in San Francisco. This material provides invaluable data for geologic mapping and studies related to the environments of deposition of oceans covering California during the past 200 million years.

\section{ACKNLOWLEDGEMENTS}

We are grateful to the paleontologists, geologists, and managers with Chevron, Exxon, Unocal, Shell, and Arco who provided materials for this report. USGS staff members Warren Addicott, John Barron, David Bukry, Will Elder (now at the National Park Service), David Jones (retired), Kristin McDougall, William Pierce (deceased), Charles Powell, II, and William Sliter (deceased) kindly determined the composition and age of fossils collected by Earl Brabb. Alvin Almgren, formerly with Unocal, provided data about fossils and nannoplankton and examined several recent foraminifer samples collected by Earl Brabb in the Fairfield area. Joseph Clark of Indiana University of Pennsylvania shared his paleo data from the Santa Cruz Mountains. Volunteer Larry Dickerson (deceased) helped separate and arrange the slides. Staff members Louise Dickerson and Bette Hamachi and volunteers Purty Dorn, Betty Harrod, and Karen Wild kindly made tables useful for preliminary inventories of the slides. Volunteers Mary Bowen, Troy Douthit, Erica Drescher, Domenique Granier, Sonoko Migitaka, Orland Soave, Graeme Somerville, and Samantha Woodward also helped prepare files and slides.

\section{REFERENCES}

Blake, M. C., Jr., Graymer, R. W., and Jones, D. L., 2000, Geologic map of parts of Marin, San Francisco, Alameda, Contra Costa, and Sonoma Counties, California, with a digital database by Adam Soule and R. W. Graymer: U. S. Geological Survey Miscellaneous Field Studies Map MF-2337.

Blake, M. C., Jr., Graymer, R. W., and Stamski, R. E., 2002, Geologic map and map database of western Sonoma, northernmost Marin, and southernmost Mendocino Counties, California: U. S. Geological Survey Miscellaneous Field Studies Map MF-2402.

Brabb, E. E., 1997, Geologic map of Santa Cruz County, California; a digital database: U. S. Geological Survey Open File Report 97-489.

Brabb, E. E., 1989, Geologic map of Santa Cruz County, California: U. S. Geological Survey Miscellaneous Geologic Investigations Map I-1905, scale 1:62,500.

Brabb, E. E., Graymer, R. W., and Jones, D. L., 1998, Geology of the onshore part of San Mateo County, California; a digital database: U. S. Geological Survey Open File Report 98-137.

Brabb, E.E., and Pampeyan, E.H., 1983, Geologic map of San Mateo County, California: U.S. Geological Survey Miscellaneous Investigations Map I-1257A. 
प Brabb, E. E., and Parker, J. M., 2003, Location and age of foraminifer samples collected by Chevron petroleum geologists in California: U. S. Geological Survey Open File Report 03-167, 9p.

Brabb, E. E., Sonneman, H. S., and Switzer, J. R., Jr., compilers, 1971, Preliminary geologic map of the Mount Diablo-Byron area, Contra Costa,, Alameda, and San Joaquin Counties, California: U. S. Geological Survey Open File Report 71-0053, scale 1:62,500.

Goudkoff, O. S., 1945, Stratigraphic relations of the Upper Cretaceous in the Great Valley of California: American Association of Petroleum Geologists Bulletin, v. 29, p. 956-1007.

Graymer, R. W., Jones, D. L., and Brabb, E. E., 1994, Preliminary geologic map emphasizing bedrock formations in Contra Costa County, California, a digital database: U. S. Geological Survey OpenFile Report 94-622, scale 1:100,000, pp. 30.

Graymer, R. W., Jones, D. L., and Brabb, E. E., 1996, Preliminary geologic map emphasizing bedrock formations in Alameda County, California, a digital database: U. S. Geological Survey Open-File Report 96-252.

Graymer, R. W., Jones, D. L., and Brabb, E. E., 2002, Geologic map and map database of the northeastern San Francisco Bay region: U. S. Geological Survey Miscellaneous Field Studies Map MF-2403.

Graymer, R. W., Jones, D. L., and Brabb, E. E., 2002a, 2002b in press, Geologic map and map database of eastern Sonoma and western Napa Counties, California: U. S. Geological Survey Miscellaneous Field Studies Map

Jachens, R. C., Sikora, R. F., Brabb, E. E., Wentworth, C. M., Brocher, T. M., Marlow, M. S., Roberts, C. W., 1997, The basement interface - San Francisco Bay area, California, 3-D seismic velocity model: American Geophysical Union Program with Abstracts, San Francisco Meeting, 1997, p. F-436.

Kleinpell, R. M., 1938, Miocene stratigraphy of California: Tulsa, OK, American Association of Petroleum Geologists, 450p.

Laiming, Boris, 1940, Foraminiferal correlations in Eocene of San Joaquin Valley, California: American Association of Petroleum Geologists Bulletin v. 24, p. 1923-1939.

Sims, J. D., Fox, K. F., Jr., Bartow, J. A., and Helley, E. J., 1973, Preliminary geologic map of Solano County and parts of Napa, Contra Costa, Marin, and Yolo Counties, California: U. S. Geological Survey Miscellaneous Field Studies Map MF-484, scale 1:62,500.

Wentworth C. M., Blake, M. C., Jr., McLaughlin, R. J., and Graymer, R. W., 1999, Preliminary geologic map of the San Jose 30 x 60 minute quadrangle, California: U. S. Geological Survey Open File Report 98-795.

Wentworth, C. M., Fumal, T. S., Brocher, T. M., and Brabb, E. E., 1997, The areal distribution of geologic materials and their seismic velocities, San Francisco Bay region, California: American Geophysical Union Program with Abstracts, San Francisco Meeting, 1997, p. F-436. 